\title{
AGE DISCREPANCIES WITH THE RADIOCARBON DATING OF SAGEBRUSH (ARTEMISIA TRIDENTATA NUTT.)
}

\author{
Phil R Geib \\ Department of Anthropology, University of New Mexico, MSC01-1040, 1 University of New Mexico, Albuquerque, New \\ Mexico 87131-0001, USA. Email: pgeib@unm.edu.
}

\begin{abstract}
When ancient hearths at open archaeological sites do not yield carbonized annual plant remains or other highquality samples, wood charcoal is commonly used for radiocarbon dating. Sagebrush (Artemisia tridentata Nutt.), a shrub frequently used for fuel across much of the western United States, seems a potentially better candidate for ${ }^{14} \mathrm{C}$ dating than tree wood since the possibility for significant age discrepancy might be less. A comparison of multiple assays from single features reveals that sagebrush can overestimate age more than even tree wood charcoal. A plausible cause of this appears to be persistence of the shrub on the ground surface for an extended interval after death, such that use as fuel almost invariably occurs hundreds of years after fixation of carbon. The potential for age discrepancy may decrease as population density increases because the demand for fuel wood would have resulted in a more rapid turnover of the fuel biomass. This is not true for Archaic period foragers of western North America when population levels were likely quite low and residential mobility quite high.
\end{abstract}

\section{INTRODUCTION}

Like elsewhere in the world, radiocarbon dating of open sites in the North American Southwest usually depends on amorphous carbon, preferably from definable features such as hearths. This is especially true for sites of the Archaic period (some 9000-3000 yr ago) when little else is available. Bone can be poorly preserved, if at all, especially in the earliest sites, and when present it often lacks datable collagen. Seeds of annual plants have the potential to closely correspond to the target event, but plant remains other than tiny charcoal pieces are exceedingly rare occurrences in hearths at open Archaic-age sites. In some parts of the world, this is unlikely to present a problem, but in the arid conditions of the West, slow tree growth coupled with slow wood decay can result in significant age discrepancies that complicate the interpretation of results - the "old wood" problem (e.g. Smiley 1985, 1998a,b; Schiffer 1986). In such settings, the burning of fuel frequently occurs several hundred years or more after the fixation of carbon in plant cellulose. Sagebrush (Artemisia tridentata Nutt.), a shrub frequently used for fuel, seems a potentially better candidate for ${ }^{14} \mathrm{C}$ dating than tree wood since the possibility for significant age discrepancy should be less: shorter lifespan, thus less age difference between pith and exterior growth rings (cross-sectional effect, see Smiley 1998a) and quicker turnover in the environment under the presumption that the small-diameter twigs of this shrub would more readily decompose in the open than tree limbs. The assumption of less age discrepancy was tested using a series of comparative dates on sagebrush charcoal and conifer wood charcoal and other remains from single features at sites on the Colorado Plateau of SE Utah and NE Arizona. The results reveal that sagebrush overestimates age compared to annual plants remains and other high-quality samples, as would be expected. Surprisingly, however, sagebrush can also produce greater age discrepancies than even conifer tree charcoal. The cause of this appears to be persistence of the shrub on the ground surface for an extended interval after death, such that use of the wood as fuel can occur hundreds of years after fixation of carbon. The counterintuitive finding that sagebrush charcoal can produce even greater age disparities than tree charcoal reveals the need for careful evaluation of how well sample materials relate to the behavioral events of interest and degree of temporal resolution required.

\section{BACKGROUND}

During the 1990s, while employed by the Navajo Nation, I directed a large contract excavation project on Navajo Tribal Land in advance of the proposed paving of a graded dirt road to Navajo 
Mountain in NE Arizona and SE Utah, USA (Figure 1; Geib and Spurr 2007). This multiyear effort, known as the Navajo Mountain Road Archaeological Project (NMRAP), involved the complete or partial excavation of 33 prehistoric sites comprising 58 separate temporal components that ranged in age from the early Archaic, almost $9000{ }^{14} \mathrm{C}$ yr ago, up to around AD 1300. This sample included 16 Archaic sites or site components and 17 sites/components from the initial farmer presence in the area known as Basketmaker II. ${ }^{14} \mathrm{C}$ dating was essential for the temporal placement of these remains, with 59 dates obtained for the Archaic sites and 75 for the Basketmaker sites.

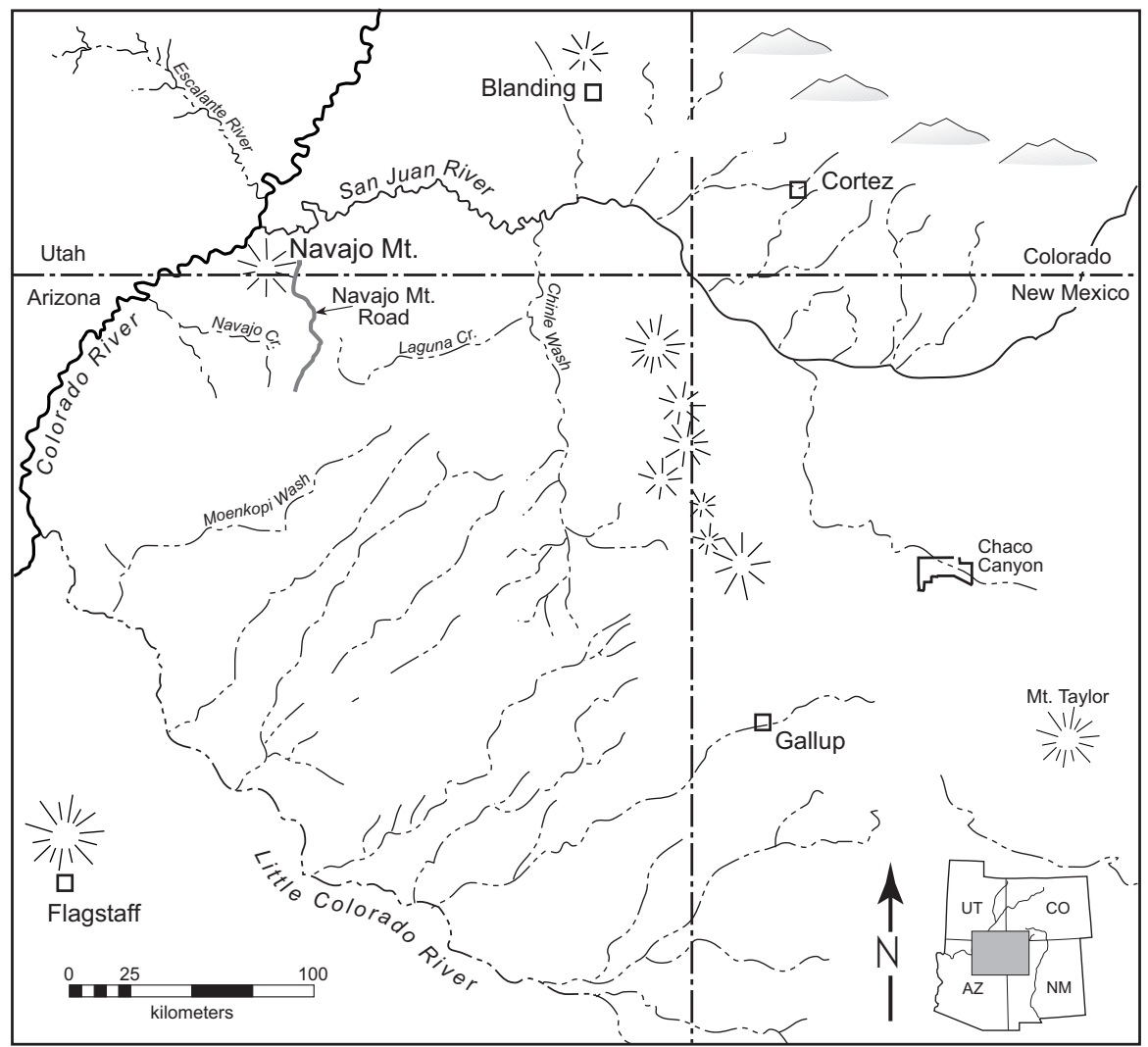

Figure 1 Map of the Four Corner region of the Colorado Plateau showing the general location of the Navajo Mountain Road, along which archaeological excavations provided the samples discussed in this report.

Maize (Zea mays), with its durable, large, and easily recognizable parts, was present at virtually all of the Basketmaker II sites, and direct accelerator mass spectrometry (AMS) dating of this humancontrolled annual plant allowed for accurate chronological placement (Geib and Spurr 2000; Geib 2007b). Maize remains were readily recovered from most Basketmaker sites while excavating features, although in some cases samples had to be retrieved by flotation of sediment samples. The AMS technique was used almost exclusively for dating the Basketmaker II sites given the sample sizes involved-single maize kernels or cob cupules.

${ }^{14} \mathrm{C}$ dating for the Archaic period sites was less ideal because a high percentage of the dates had to be based on samples of wood charcoal, a low-quality material (see Smiley 1998a:39-40), in settings that favor wood preservation. Several studies have shown that wood charcoal in the arid North 
American Southwest routinely overestimates the age of cultural events because hundreds of years usually have elapsed between the death of woody plants and their use as fuel (Schiffer 1986; Smiley 1985, 1998b). Moreover, since many trees of the region are slow growing and very long lived (e.g. pinyon [Pinus spp.] and juniper [Juniperus spp.], the common trees represented in hearth charcoal), hundreds of years often separate plant death from prior annual events of carbon fixation.

The Archaic hearths excavated by the NMRAP contained variable amounts of carbon, with age appearing to be a principal determinant-less carbon with age, especially in the easily recoverable form of charcoal pieces. Depth and rapidity of burial also play an important role in that hearths closer to the surface have greater exposure to destructive forces (Geib 2007a: Table 4.2). Most hearths consisted of shallow basins filled with charcoal-stained sediment containing generally sparse charcoal flecks. Mechanical processes (alternating wet/dry, freeze/thaw, plus intensive root and animal activity) appear to have reduced the carbonized fuel of these features to charcoal dust. Rarely were identifiable plant portions other than minute charcoal pieces of trees or shrubs recovered from hearth fill either in the field during excavation or sediment screening or by subsequent water flotation of sediment samples. For example, an analysis of 25 flotation samples totaling $97 \mathrm{~L}$ of sediment from 25 hearths at 8 early Archaic open sites (about 8400-6000 BP) resulted in the recovery of just 9 burned seed fragments from 5 taxa, mostly Chenopodium sp. (Geib 2007a: Table 4.1). The minute size of these remains, often $<0.001 \mathrm{~g}$ in weight, would have challenged the AMS technique to provide accurate dates. Preservation was no better at late Archaic (about 4000-2800 BP) sites except for one that had been deeply (up to $1.4 \mathrm{~m}$ ) and rapidly buried by eolian sand.

As it turned out, most NMRAP Archaic hearths yielded nothing other than wood charcoal for ${ }^{14} \mathrm{C}$ analysis, and usually the total amount of tiny flecks weighed $<1 \mathrm{~g}$. Inspection of samples prior to submission for dating revealed that in many cases the charcoal pieces consisted of sagebrush in addition to those from trees such a juniper (J. monosperma and J. osteosperma) and pinyon (Pinus edulis). Intuitively, it seemed that the wood of a shrub used for fuel would provide an assay more closely corresponding to the time of a fire than an assay on tree wood, especially for charcoal from slowgrowing and long-lived trees such as pinyon and juniper. Two lines of reasoning go into this assessment: 1) sagebrush is short lived compared to pinyon or juniper, usually surviving $<100 \mathrm{yr}$; thus, there is less cross-sectional affect (carbon is fixed over a limited period); 2) the small-diameter twigs and branches of sagebrush would be less likely than tree wood to survive in the open for extended periods of time, several hundreds of years, up to a thousand or more documented for tree wood. (The fixed carbon of sagebrush will not survive as long in the environment prior to burning.)

The impression that sagebrush assays closely correspond in time to the behavioral event of interest was initially supported early in the project by 2 assays on sagebrush from hearths at a Puebloan site, assays that closely corresponded to a tree-ring date on wood from one of the dated features. The mean $(972 \pm 38 \mathrm{BP})$ of the nearly identical sagebrush ${ }^{14} \mathrm{C}$ dates $(980 \pm 50 \mathrm{BP},-25.1 \%$, Beta-79157; $960 \pm 60 \mathrm{BP},-22.4 \%$ o, Beta-79156) has a calibrated 2- $\sigma$ range of AD 990 to 1170 (OxCal 3.10; Bronk Ramsey 1995, 2001) that is almost identical to the spread of annual rings on a carbonized juniper $\log$ from one of the hearths, which has an inner ring of AD 937 and a near cutting date $(+r)$ of AD 1132 (TRL No. NMR-28 [a,b], Laboratory of Tree-Ring Research, Tucson, Arizona, USA). Thus, until near the end of the project I considered sagebrush more likely to provide accurate dates than tree charcoal and would submit sagebrush whenever this material was found in hearth fill. It was by analyzing samples during the course of this project that I began to have suspicions about my preference for sagebrush and the last year of fieldwork provided excellent samples for testing this notion. The findings, which are presented and discussed below, indicate that sagebrush is not necessarily a better material for dating than wood charcoal and indeed is more likely to provide an older 
temporal estimate than does wood charcoal, which might itself also be offset from the true age of interest.

\section{MATERIALS AND METHODS}

\section{Prehistoric Samples}

The specifics of ${ }^{14} \mathrm{C}$ dating for the NMRAP are described in Geib and Spurr (2007). The project used Beta Analytic (Miami, Florida, USA) as the primary contractor for ${ }^{14} \mathrm{C}$ dating services. All of the standard beta-decay counting was done in-house at Beta Analytic, along with the pretreatment of AMS samples and conversion to graphic targets; all AMS dating was done at Lawrence Livermore National Laboratory (Livermore, California, USA), one of Beta's consortium accelerator laboratories. I insisted on the use of a single AMS facility to help reduce potential problems with interlaboratory comparability, an issue that arose with a few Basketmaker II samples early in the project.

In sampling Archaic features for purposes of ${ }^{14} \mathrm{C}$ dating, excavators endeavored to recover charcoal or higher quality carbonized plant remains in the field, either directly during feature excavation or, if failing this, while screening fill thorough $1 / 8^{\prime \prime}$ mesh. The alternative strategy was to use carbonized remains separated from flotation samples. In no case did I rely on bulk sediment samples from hearths given a lack of knowledge about what was being dated and the chance for contamination by more recent carbon, especially humic acids. ${ }^{1}$ The amount of carbon collected for any specific Archaic hearth was variable, but a general goal was to collect enough for a standard beta-decay date. Given that temporal placement of Archaic sites would be based largely on wood charcoal, there was every reason to submit sufficient material to allow for beta-decay counting rather than the more costly AMS analysis. I could have dated single charcoal pieces by AMS, but there is no reliable way of knowing beforehand which piece most closely approximates the episode of burning, and the one chosen might be very ancient. Assaying numerous charcoal chunks results in a date that is an "average" for many separate individual ages (the average age of carbon fixation represented by each charcoal chunk), which reduces the relative contribution of extremely old wood (Smiley 1985:72). By these means, I reserved funds so that the more costly AMS analysis could be used for Basketmaker II chronology where the better resolution provided by dating single annual plant remains had greater value. As it turned out, I also often had to use AMS analysis to date Archaic hearths since they frequently yielded just a smattering of tiny charcoal flecks that weighed $<0.1 \mathrm{~g}$. In several cases, extended counting was employed for small standard samples.

As a general rule, small Archaic features such as hearths were dated by single assays, but at one point halfway through the project I submitted 2 distinct samples-conifer tree and sagebrush charcoal-from a single hearth at the site of Tres Campos (AZ-J-14-12). These paired samples provided the first hint that sagebrush might provide larger age discrepancies than tree charcoal. In this instance, the sagebrush assay was $380{ }^{14} \mathrm{C}$ yr older than the tree charcoal assay, which itself might also be too old. This result raised a red flag, but at the time it was but a single discrepancy. Excavation of superimposed late Archaic components at Three Dog Site (UT-B-63-39) during the final season of NMRAP fieldwork presented an excellent opportunity to test the notion of age overestimation with sagebrush. The hearths at this site contained abundant carbonized remains, ${ }^{2}$ many

\footnotetext{
${ }^{1}$ A similar excavation project on Navajo Tribal land that relied primarily on bulk sediment samples for dating Archaic hearths almost created a nonexistent middle Archaic occupation since the bulk samples invariably underestimated the age of the features by anywhere from 1000 to $4000 \mathrm{yr}$ (Bungart et al. 2004).

${ }^{2}$ The unusually good preservation in this case resulted from rapid and deep eolian burial of the Archaic features by up to $1.4 \mathrm{~m}$ of eolian sand.
} 
containing both wood and sagebrush charcoal and a few with enough of both materials to obtain standard beta-decay dates. A few of the features also contained juniper seeds. Further comparisons were made using samples from Basketmaker sites where assays on annual plant remains could be compared with those on sagebrush. By the end of project, I had ${ }^{14} \mathrm{C}$ results to make 8 comparisons, 6 from Archaic hearths and 2 from features at 2 Basketmaker II sites.

\section{Modern Samples}

In an effort to obtain a modern comparative gauge for measuring the potential discrepancy in age between use of sagebrush as fuel and a resulting ${ }^{14} \mathrm{C}$ determination, I directly dated sagebrush specimens present on the ground surface of the region today. Samples were collected from several sagebrush specimens in various states of decay, and 2 of these samples were submitted to Beta Analytic for standard beta-decay ${ }^{14} \mathrm{C}$ dating. One sagebrush was a standing dead plant that still retained most of its small twigs (Shrub A) and the other was from a fallen plant that had rotted through at the base, with small twigs gone and the wood somewhat decayed but in good condition to serve as fuel (Shrub C). The samples were soaked in distilled water and carefully scrubbed prior to submission to the dating laboratory in order to remove lichens and moss growing on the wood-modern contaminants that might not be eliminated in standard chemical pretreatment.

\section{RESULTS}

\section{Archaic Hearths}

Table 1 and Figure 2 present a within-feature comparison of ${ }^{14} \mathrm{C}$ dates at 2 different Archaic sites; assays are based on sagebrush charcoal as opposed to those based on tree charcoal or juniper seeds. There are 6 different comparisons. In all but 1 case (83\%), the dates are statistically different with a $95 \%$ probability limit. In 4 of 6 cases $(67 \%)$, the sagebrush charcoal returned ages significantly older than tree charcoal and juniper seeds: a 380-yr difference between the 2 dates for Hearth 1 at Tres Campos, a 230-yr difference between the 2 dates for Hearth 4 at Three Dog Site, a 220-yr difference between the 2 dates for Hearth 20 at Three Dog Site, and a 210-180 yr difference between the sagebrush date and the other 2 dates for Hearth 13 at Three Dog Site. Two aspects of this are worth calling attention to. First, the Hearth 4 sagebrush date is on a tiny twig $2 \mathrm{~mm}$ in diameter, a seemingly improbable item to overestimate age. Second, the 2 non-sagebrush dates for Hearth 13 are statistically the same and produce an average $(2903 \pm 35$ BP) with even less overlap with the sagebrush date given its smaller error term.

Although sagebrush commonly resulted in ages that were older than tree charcoal, this was not always true as indicated by Hearth 1 at Three Dog Site, whose 2 dates are virtually identical. What remains unknown in this case is whether both material types equally overestimate the age of the fire-the tree charcoal in this instance is as unreliable as the sagebrush-or whether both samples represent the true antiquity of the feature (the former seems most likely). The samples for Hearth 2 at Three Dog Site actually resulted in a reverse pattern, with the sagebrush charcoal producing a date significantly younger than the tree charcoal date. In this case, the sagebrush date might be more likely, but overall it appears safe to conclude that sagebrush is no better than tree charcoal when it comes to accurately estimating the age of past occupations and indeed it is more likely to be worse.

In each of these 4 cases, it is expected that the tree charcoal assays are themselves offset from the true times of the fires. Smiley's (1998c: Table 7-2) analysis of charcoal dates from Basketmaker II sites on Black Mesa showed that just 15\% fell within the Lolomai phase occupation span as estimated by 6 maize dates, with a full $85 \%$ overestimating true site age; almost half of these were too 
Table 1 Comparison of ${ }^{14} \mathrm{C}$ determinations on sagebrush and tree charcoal (chiefly pinyon and juniper) or juniper seeds from single features at NMRAP Archaic sites (calibrations and testing for significance based on OxCal 3.10 [Bronk Ramsey 1995, 2001]).

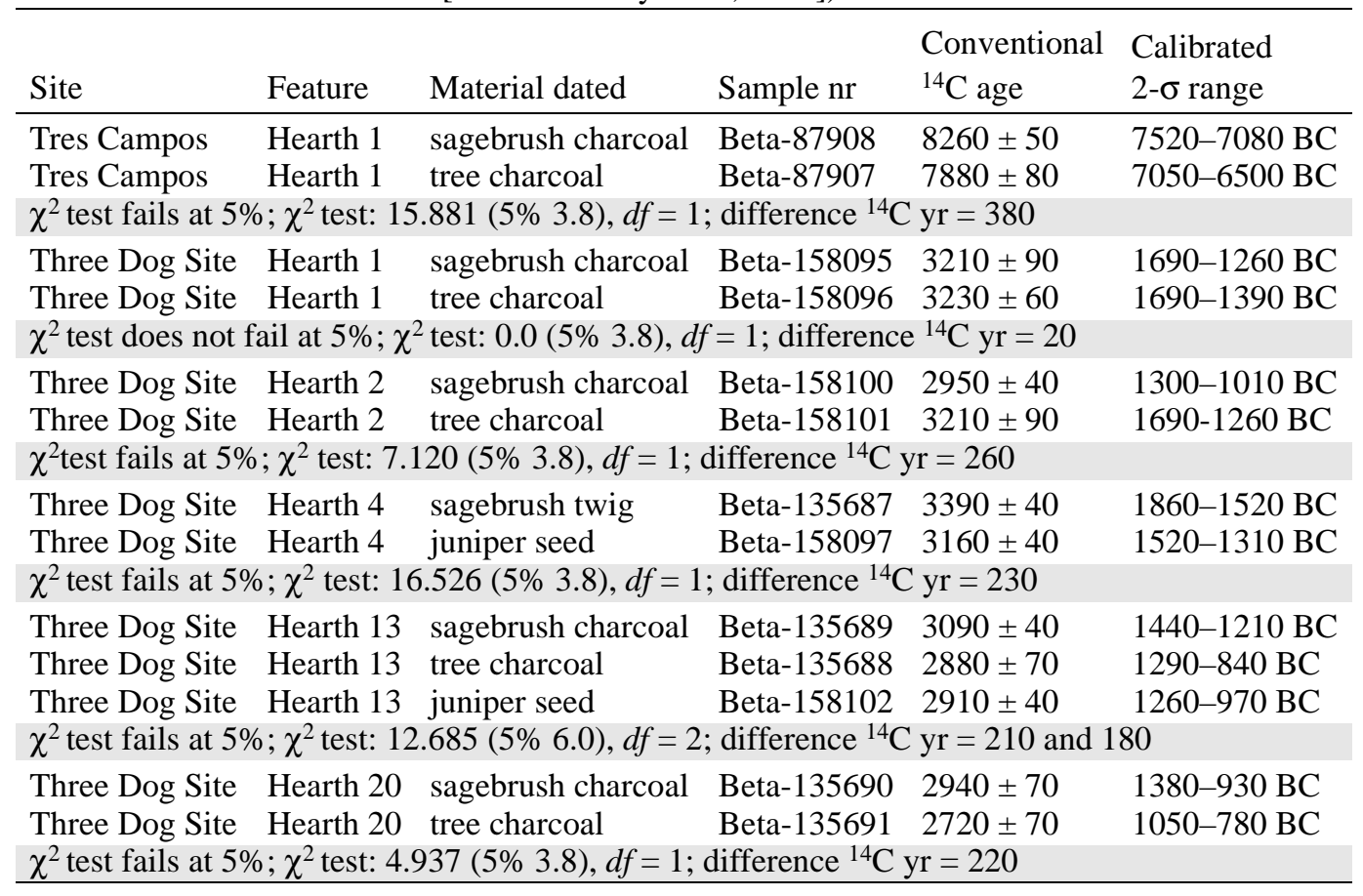

old by $100 \mathrm{yr}$ or more with $30 \%$ of them overestimating site age by $200 \mathrm{yr}$ or more. If true in these NMRAP instances, then the sagebrush dates are even more erroneous in that they are compared against dates that are perhaps too old themselves. Comparison of sagebrush charcoal dates against maize and other remains at 2 Basketmaker sites allows examination of this possibility.

\section{Basketmaker II Sites}

${ }^{14} \mathrm{C}$ dates from 2 Basketmaker sites allow comparisons of sagebrush assays against those on highquality materials. At the site of Ditch House (AZ-J-14-21), there are $4{ }^{14} \mathrm{C}$ dates from 3 individual features (Figure 3). One date is on carbonized sagebrush wood from a concentration of burned rock, whereas the other 3 dates are on other remains: maize cupules, a pinyon cone scale, and pinyon bark. The maize and cone scale came from a structure hearth and produced similar assays that are statistically the same and can be averaged $(2059 \pm 33 \mathrm{BP})$. The spread on the 4 Ditch House dates extends from just under 400 cal BC to just over cal AD 100; the dates are significantly different $\left(\chi i^{2}=15.2\right.$, $5 \%=6.0[d f=3])$. The $2180 \mathrm{BP}$ sagebrush date from the burned rock concentration appears most at odds, and indeed a test shows that the structure date average and that for a storage pit are statistically the same $\left(\chi i^{2}=3.6,5 \%=3.8[d f=1]\right)$. Given the small size of the Basketmaker component at Ditch House and the presence of only 1 true living structure, the Basketmaker remains at this location are likely the residue of a moderately short-lived occupation rather than one of several hundred years or a few sequential use episodes. Because the determinations for structure and pit are statistically the same, their average of $2019 \pm 25 \mathrm{BP}$ provides the best temporal estimate for the Basketmaker component at Ditch House, which has a 2- $\sigma$ range of cal 100 BC to AD 60. The carbonized sagebrush of the burned rock concentration is $100-200{ }^{14} \mathrm{C}$ yr older because of burning dead shrubs. 
Tres Campos

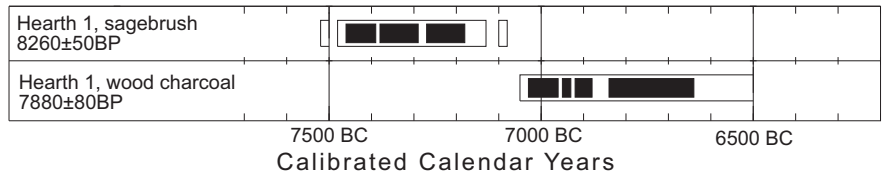

Three Dog Site

\begin{tabular}{|l|l|l|}
\hline $\begin{array}{l}\text { Hearth 1, sagebrush } \\
3210 \pm 90 \mathrm{BP}\end{array}$ \\
\hline $\begin{array}{l}\text { Hearth 1, wood charcoal } \\
3230 \pm 60 \mathrm{BP}\end{array}$ \\
\begin{tabular}{|l|l|}
\hline Hearth 2, sagebrush \\
$2950 \pm 40 \mathrm{BP}$
\end{tabular} \\
\hline $\begin{array}{l}\text { Hearth 2, wood charcoal } \\
3210 \pm 90 \mathrm{BP}\end{array}$
\end{tabular}

\begin{tabular}{|l|l|}
\hline Hearth 4, sagebrush twig \\
$3390 \pm 40 \mathrm{BP}$
\end{tabular}

\begin{tabular}{|l|l|}
\hline $\begin{array}{l}\text { Hearth 13, sagebrush } \\
3090 \pm 40 \mathrm{BP}\end{array}$ \\
Hearth 13, wood charcoal \\
Hearth 13, juniper seed \\
$2910 \pm 40 \mathrm{BP}$
\end{tabular}

Hearth 20, sagebrush
$2940 \pm 70 \mathrm{BP}$

Figure 2 Comparison of ${ }^{14} \mathrm{C}$ determinations on sagebrush and wood charcoal from single features at NMRAP Archaic sites (1- $\sigma$ ranges shown by solid black boxes and 2- $\sigma$ ranges by enclosing boxes).

\begin{tabular}{|l|l|}
\hline $\begin{array}{l}\text { sagebrush, } 2180 \pm 40 \mathrm{BP} \\
\text { Burned Rock Concentration }\end{array}$ & $\begin{array}{l}\text { maize cupules, } 2080 \pm 40 \mathrm{BP} \\
\text { Structure } 6\end{array}$ \\
\hline $\begin{array}{l}\text { pinyon cone scale, } 2010 \pm 60 \mathrm{BP} \\
\text { Structure } 6\end{array}$ & $\begin{array}{l}\text { 200 BC } \\
\text { pinyon bark, } 1960 \pm 40 \mathrm{BP}\end{array}$ \\
\hline Storage Pit 1
\end{tabular}

Figure 3 Comparison of ${ }^{14} \mathrm{C}$ determinations on sagebrush, maize cupules, a pinyon cone scale, and pinyon bark from various Basketmaker features at Ditch House (1- $\sigma$ ranges shown by solid black boxes and $2-\sigma$ ranges by enclosing boxes).

The Basketmaker II component at Three Dog Site provides yet another case where a sagebrush charcoal assay can be compared against assays on annual plant remains. The initial date for this compo- 
nent of $2020 \pm 40$ BP (Beta-135694) consisted of sagebrush charcoal from 2 overlapping hearths. The subsequent processing and analysis of 2 flotation samples from the hearths recovered annual plant remains, including ricegrass seeds and a maize kernel fragment. These 2 samples returned statistically contemporaneous ${ }^{14} \mathrm{C}$ dates in the 1800 s BP (Figure 4), with an average of $1830 \pm 28 \mathrm{BP}$, almost $200{ }^{14} \mathrm{C}$ yr more recent than the previous sagebrush date.

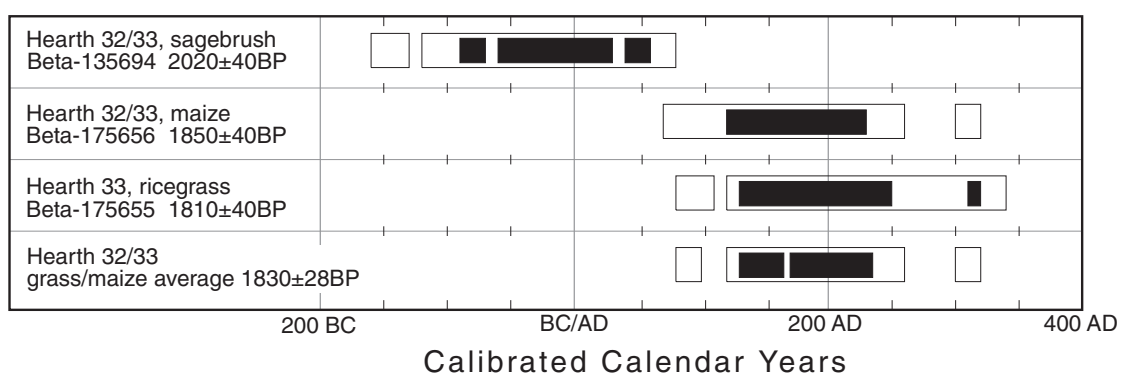

Figure 4 Comparison of ${ }^{14} \mathrm{C}$ determinations on sagebrush, maize cupules, and ricegrass seeds from Basketmaker hearths at Three Dog Site (1- $\sigma$ ranges shown by solid black boxes and 2- $\sigma$ ranges by enclosing boxes).

\section{Modern Samples}

The results of dating modern sagebrush specimens (Table 2) show that the standing dead shrub was alive and respiring carbon after the start of atomic bomb testing in the 1950s. The sample contained more ${ }^{14} \mathrm{C}$ than the AD 1950 reference standard. The fallen and partially decayed shrub was not enriched in ${ }^{14} \mathrm{C}$, so it must predate 1950 ; it returned an assay of $120 \pm 50 \mathrm{BP}$ with a calibrated $2-\sigma$ range of $\mathrm{AD} 1670-1960$.

Table $2{ }^{14} \mathrm{C}$ dates on 2 samples of sagebrush collected in 2002 (samples were not corrected for fractionation but have an assumed $\delta^{13} \mathrm{C}$ value of $-25.0 \%$; calibrations based on OxCal 3.10 [Bronk Ramsey 1995, 2001]).

\begin{tabular}{|c|c|c|c|c|}
\hline Sample ID & Shrub condition & Laboratory nr & $\begin{array}{l}\text { Conventional } \\
{ }^{14} \mathrm{C} \text { age }\end{array}$ & $\begin{array}{l}\text { Calibrated } \\
2-\sigma \text { range }\end{array}$ \\
\hline Shrub A & $\begin{array}{l}\text { Standing dead with } \\
\text { small twigs intact }\end{array}$ & Beta-175492 & $120.92 \pm 0.72 \mathrm{pMC}^{\mathrm{a}}$ & modern \\
\hline Shrub C & $\begin{array}{l}\text { Fallen, small twigs } \\
\text { missing, wood intact }\end{array}$ & Beta-175493 & $120 \pm 50$ & AD 1670-1960 \\
\hline
\end{tabular}

\section{DISCUSSION}

Sagebrush is not known to be a long-lived shrub; "it commonly reaches 40 to 50 years of age, and some plants may exceed 100 years" (www.fs.fed.us/database/feis/). Ferguson (1964) reported a maximum age of $217 \mathrm{yr}$, but this is an extreme outlier; another study in Wyoming found a maximum age of $81 \mathrm{yr}$, also an extreme outlier (Perryman et al. 2001). Cawker's (1980) study of 1276 sagebrush sections showed that the vast majority are $<20 \mathrm{yr}$ old with a distinct grouping of "older" shrubs between 30 and $60 \mathrm{yr}$ of age and none past 85 (Cawker 1980: Figure 3). Perryman et al. 
(2001: Table 1) found that sagebrush in various stands in Wyoming ranged in mean and median ages from between 14 and $50 \mathrm{yr}$ (total sample size was some 2200 plants with anywhere from 59 to 224 per stand). At a Nevada site, the oldest sagebrush had $<59$ annual rings (Biondi et al. 2007). Even if rare individuals live more than $100 \mathrm{yr}$, pinyon and juniper trees normally live for hundreds of years (Jeffrey Dean, personal communication, 1996). Consequently, it is probably not the overall lifespan of sagebrush that causes age overestimation in that carbon is fixed within a relatively short interval, especially compared to the common tree species of the Colorado Plateau.

Excluding longevity in life, then longevity after death is a plausible reason for age overestimation. At any particular place on the Colorado Plateau, or elsewhere in the West, one sees sagebrush in various states of life and death-from flourishing to dying to badly decayed hulks. Minus metal tools, as would have been the case in the prehistoric Southwest, this shrub is hard to tear from the ground when alive, whereas dead shrubs are often easily yanked free owing to termite activity and basal rot. The more advanced the decay, the easier the shrub is to procure and tear asunder. Eventually, shrubs fall over of their own accord and enter an even more advanced state of decay. In collecting sagebrush for fuel, the dead and down shrubs would seem to be natural choices since they require the least work (pick up pieces and move along). The question is, how long does it take for sagebrush to reach this optimal state for fuel use: $50 \mathrm{yr}, 100 \mathrm{yr}, 200 \mathrm{yr}$, more?

I directly dated sagebrush specimens present on the ground surface of the region today to try and answer this question. The modern samples provide initial confirmation of the suspected reason behind the probability that ${ }^{14} \mathrm{C}$ dates on sagebrush used for fuel will overestimate the age of a cultural event. Sagebrush might have a particularly long "shelf life" as fuel in that it might take $50 \mathrm{yr}$ or more for a dead shrub to fall over and then hundreds of years before the wood is so sufficiently decayed and scattered that it would no longer be collected for burning. As a result, there is no reason to privilege carbonized sagebrush over that of tree wood for the ${ }^{14} \mathrm{C}$ dating of prehistoric features, and indeed the reverse might be true.

The potential for age discrepancy with short-lived shrubs that have a potentially long shelf life is to a large extent related to the local rate of fuel consumption. This is basically a density-dependent phenomenon in that areas with sparse population and high residential mobility will have a far lower rate of fuel consumption than those with greater population density and substantial residential stability. The former was evidently true during the Archaic interval in the North American Southwest, whereas the latter characterizes the Puebloan period for this same region (about AD 500 to the historic era). As a result, sagebrush might provide more reliable results during more recent intervals, as was exemplified by the sagebrush sample from a Puebloan hearth reported herein that closely corresponded to the tree-ring date for a charred log from this same feature. Further back in time during the Archaic period, when the ${ }^{14} \mathrm{C}$ technique has increased significance because reliable dating alternatives are lacking, relatively sparse population and dispersed settlement would allow dead sagebrush to accumulate such that the chances of age overestimation are increased.

\section{CONCLUSIONS}

Using sagebrush charcoal for the purposes of ${ }^{14} \mathrm{C}$ dating is unlikely to avoid potential problems of age overestimation, especially during times of overall low rates of fuel wood consumption. The comparisons herein of assays on sagebrush and other materials, including annual plant remains, reveals that sagebrush is quite likely to overestimate the true age of a target event by a few hundred years. Sagebrush is even likely to produce ages a few hundred years older than the ages provided by charcoal from long-lived trees. The extent to which these findings can be extended across the full geographic range of sagebrush (from Arizona to Canada) requires further study. 
During the course of the excavation project that generated the data for this paper, I favored sagebrush charcoal over that of trees for the purposes of dating open Archaic sites that did not yield higher quality carbon samples such as annual plant remains. Were I to direct another project in a similar environment, I would have no such sagebrush preference, even if small twigs of the material are present. Sagebrush leaves would be another matter, but these are unlikely to be preserved at the open sites that provided the samples considered here.

The extent of concern with age overestimation obviously depends upon the desired degree of temporal resolution. For much of the Archaic period in the Southwest, several hundred years of age offset does not present insurmountable interpretive problems. Because of the overall coarse temporal resolution for the Archaic and the millennial intervals used for comparative and interpretive purposes, even a 500-yr age discrepancy resulting from the burning of very old wood is of relatively minor consequence. One critical issue is not to overinterpret low-quality dates from any single site as necessarily indicating overly long intervals of use or as evidence for multiple occupations. Another critical issue is with samples from late Archaic sites that approach in time the interval when domesticates (maize and squash) were introduced to the Southwest from Mesoamerica. During the agricultural transition, fine temporal resolution assumes ever greater importance and archaeologists would like to parse out occupations on the order of a generation or two (e.g. Schurr and Gregory 2002), well in excess of radiocarbon's temporal resolution, even for annual plant remains.

\section{ACKNOWLEDGMENTS}

This research was funded by the Navajo Nation Archaeology Department for a project supported by the Bureau of Indian Affairs, Navajo Area Office, Branch of Roads, Gallup, New Mexico, under the administration of the Navajo Nation Historic Preservation Department, Window Rock, Arizona. Comments from an anonymous reviewer improved the manuscript.

\section{REFERENCES}

Biondi F, Strachan SDJ, Mensing S, Piovesan G. 2007. Radiocarbon analysis confirms the annual nature of sagebrush growth rings. Radiocarbon 49(3):1231-40.

Bronk Ramsey C. 1995. Radiocarbon calibration and analysis of stratigraphy: the OxCal program. Radiocarbon 37(2):425-30.

Bronk Ramsey C. 2001. Development of the radiocarbon program. Radiocarbon 43(2A):355-63.

Bungart PB, Collette J, Spurr S. 2004. A better road ahead: archaeological excavations along Navajo Route 21 near White Mesa, Arizona [report]. Navajo Nation Archaeology Department Report No. 01-237 [manuscript on file]. Navajo Nation Historic Preservation Department, Window Rock, Arizona, USA.

Cawker KB. 1980. Evidence of climatic control from population age structure of Artemisia tridentata Nutt. in southern British Columbia. Journal of Biogeography 7:237-48

Ferguson CW. 1964. Annual Rings in Big Sagebrush: Artemisia tridentata. Papers of the Laboratory of TreeRing Research, No. 1. Tucson: University of Arizona Press. $95 \mathrm{p}$.

Geib PR. 2007a. Summary and interpretation of Archaic remains. In: Geib PR, Spurr K, editors. Prehistory of the northern Kayenta Anasazi region: archaeological excavations along the Navajo Mountain road (N16) [report]. Navajo Nation Archaeology Department Report No. 02-48, Window Rock, Arizona, USA.

Geib PR. 2007b. The first Kayentan farmers: summary and interpretation of Basketmaker II remains. In: Geib PR, Spurr K, editors. Prehistory of the northern Kayenta Anasazi region: archaeological excavations along the Navajo Mountain road (N16) [report]. Navajo Nation Archaeology Department Report No. 02-48, Window Rock, Arizona, USA.

Geib PR, Spurr K. 2000. The Basketmaker II-III transition on the Rainbow Plateau. In: Reed PF, editor. Foundations of Anasazi Culture: The BasketmakerPueblo Transition. Salt Lake City: University of Utah Press. p 175-200.

Geib PR, Spurr K. 2007. Prehistory of the northern Kayenta Anasazi region: archaeological excavations along the Navajo Mountain road (N16) [report]. Navajo Nation Archaeology Department Report No. 02-48, Window Rock, Arizona, USA.

Perryman BL, Maier AM, Hild AL, Olson RA. 2001. Demographic characteristics of 3 Artemisia tridentata Nutt. subspecies. Journal of Range Management 54(2): 166-70.

Schiffer MB. 1986. Radiocarbon dating and the "old 
wood" problem: the case of the Hohokam chronology. Journal of Archaeological Science 13(1):13-30.

Schurr MA, Gregory DA. 2002. Fluoride dating of faunal materials by ion-selective electrode: high resolution relative dating at an Early Agricultural Period site in the Tucson Basin. American Antiquity 67(2):281-99.

Smiley FE. 1985. The chronometrics of early agricultural sites in northeastern Arizona: approaches to the interpretation of radiocarbon dates [PhD dissertation]. Ann Arbor: University of Michigan. University Microfilms.

Smiley FE. 1998a. Wood and radiocarbon dating: interpretive frameworks and techniques. In: Smiley FE, Ahlstrom RVN. Archaeological Chronometry: Radiocarbon and Tree-Ring Models and Applications from Black Mesa, Arizona. Center for Archaeological In- vestigations Occasional Paper No. 16. Carbondale: Southern Illinois University. p 25-48.

Smiley FE. 1998b. Old wood: assessing age overestimation. In: Smiley FE, Ahlstrom RVN. Archaeological Chronometry: Radiocarbon and Tree-Ring Models and Applications from Black Mesa, Arizona. Center for Archaeological Investigations Occasional Paper No. 16. Carbondale: Southern Illinois University. p 49-64.

Smiley FE. 1998c. Applying radiocarbon models: Lolomai Phase chronometry on Black Mesa. In: Smiley FE, Ahlstrom RVN. Archaeological Chronometry: Radiocarbon and Tree-Ring Models and Applications from Black Mesa, Arizona. Center for Archaeological Investigations Occasional Paper No. 16. Carbondale: Southern Illinois University. p 99-134. 